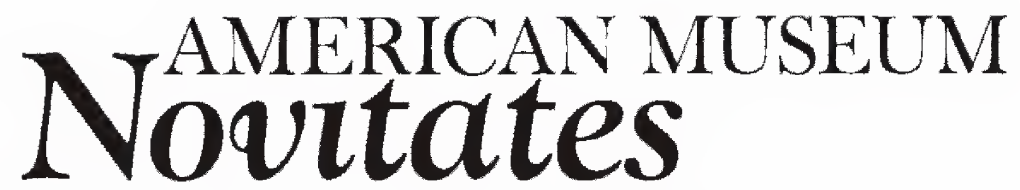

PUBLISHED BY THE AMERICAN MUSEUM OF NATURAL HISTORY CENTRAL PARK WEST AT 79TH STREET, NEW YORK, NY 10024 Number 3689, 21 pp., 10 figures

June 25, 2010

\title{
Reinterpretation of a Middle Eocene Record of Tardigrada (Pilosa, Xenarthra, Mammalia) from La Meseta Formation, Seymour Island, West Antarctica
}

\author{
R. D. E. MACPHEE ${ }^{1}$ AND M. A. REGUERO ${ }^{2}$
}

\begin{abstract}
An isolated and incomplete tooth, discovered in sediments of Middle Eocene La Meseta Fm on Seymour Island (northern Weddell Sea, West Antarctica), has previously been interpreted to be that of a sloth. The specimen as preserved is composed of dentine, as in sloths and tooth-bearing xenarthrans generally. However, characters associated with the dentinal histology of definite sloths are either not represented on the Seymour tooth, or depart considerably from tardigradan and even general xenarthran models according to new observations presented here. On the basis of histological criteria, the La Meseta tooth cannot be shown positively to be tardigradan; it may not even be xenarthran. Further progress with establishing its relationships will depend on the recovery of more (and better) specimens. For the moment, it is best attributed to Mammalia, incertae sedis.
\end{abstract}

\section{INTRODUCTION}

In 1995 Vizcaíno and Scillato-Yané reported the discovery of an unusual tooth (figs. 1, 2 ), found during the previous year at DPV locality $2 / 84$, in what is now defined as the Cucullaea I allomember of Middle Eocene La Meseta Fm, Seymour Island (see Marenssi, 2006; for abbreviations, see Materials and Methods). Although the tooth (MLP 94-III-
15-14), interpreted as an "upper caniniform lacking its base," was incomplete, the authors noted that it was composed entirely of dentine, and that there was no evidence for the prior presence of enamel (or, for that matter, cementum). Composition is significant; barring a few primitive exceptions among armadillos (Martin, 1916; Simpson, 1932), xenarthrans are the only South American land mammals whose teeth completely lack enamel.

\footnotetext{
${ }^{1}$ Division of Vertebrate Zoology/Mammalogy, American Museum of Natural History (macphee@amnh.org).

2 Departamento Scientifico de Paleontología Vertebrados, Museo de La Plata, Paseo del Bosque s/n, 1900 La Plata, Argentina (regui@fcnym.unlp.edu.ar).
} 
NO. 3689
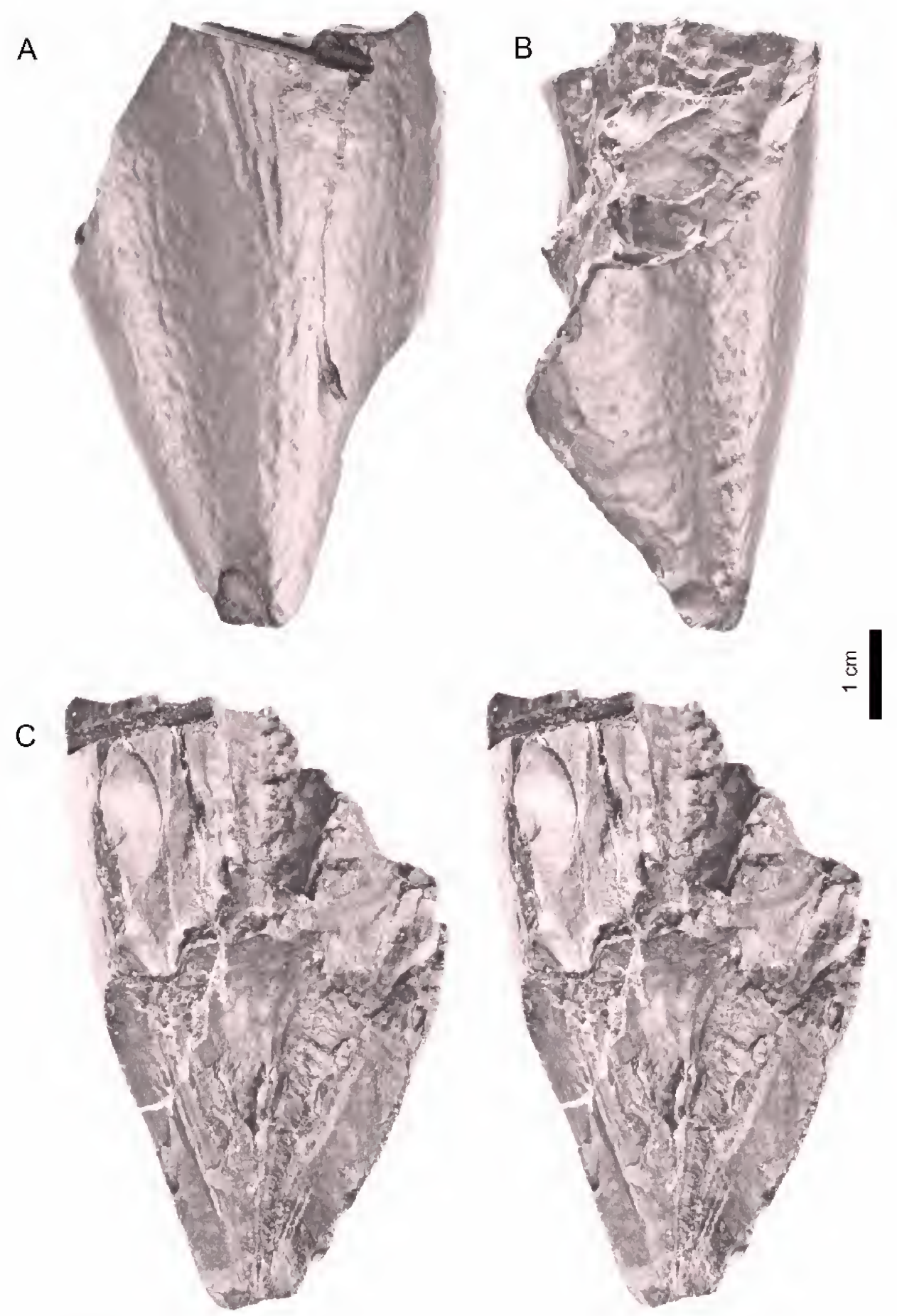

Fig. 1. MLP 94-III-15-14, incomplete tooth (19.7 mm GL at time of discovery) from La Meseta Fm, Seymour I., West Antarctica. A, apparent mesial view (assuming tooth is maxillary as stated by Vizcaíno and Scillato-Yané, 1995); B, lateral view; C, apparent distal view, stereopair; D, key to explanatory diagram: 1 , location of sample detached for SEM; 2 , parts of pulp cavity; 3 , intermediate "light layer" of Vizcaíno and 
For these and several other reasons discussed in following sections, Vizcaíno and ScillatoYané (1995) concluded that the tooth most probably belonged to a member of Xenarthra, and, given its caniniform aspect, to a tardigradan rather than a cingulatan.

As recently relimited by McKenna and Bell (1997) and McKenna et al. (2006), Tardigrada (sloths) includes the most recent common ancestor of Bradypus and Choloepus plus all of its descendants. It is thus an avowedly crown-group construction. Vizcaíno and Scillato-Yané's understanding of sloth diversity was similar, although expressed differently, and in any case no additional definition is required here. Pilosa + Cingulata with their usual definitions and content comprise McKenna and Bell's (1997) Xenarthra, now often given superordinal status. Other taxa grouped within cohort Edentata by Gaudin (2004) shed no light on the affinities of the

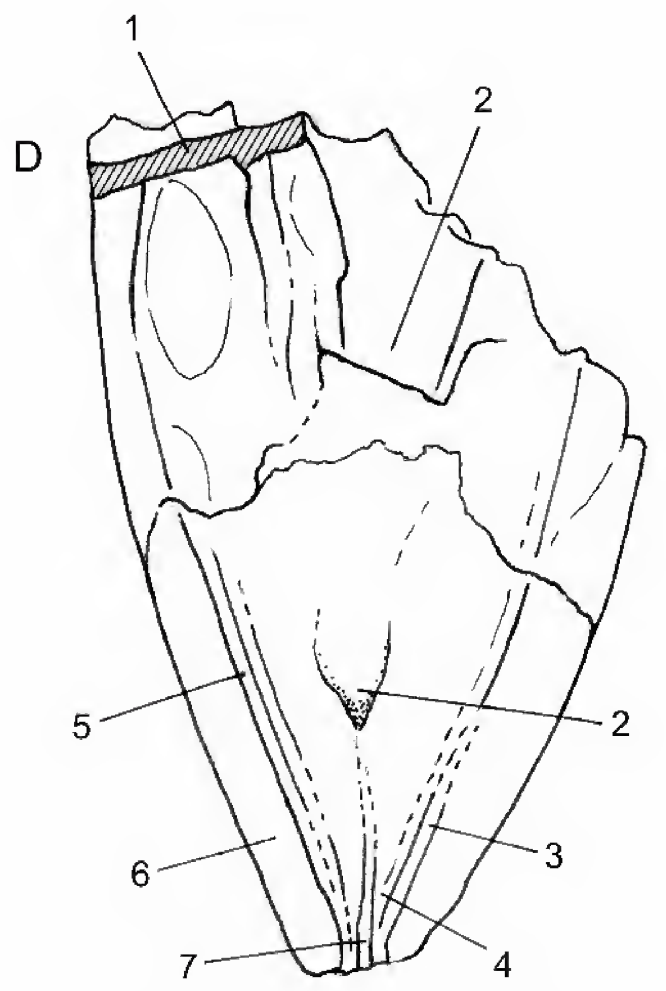

Scillato-Yané (1995); 4, numerous darker layers, stacked as chevrons (also traceable on other side); 5 , dark line between external thick layer and other layers; 6 , external thick layer of dentine; 7 , central canal. specimen in question and accordingly play no role in this analysis.

Seymour Island is situated approximately $90 \mathrm{~km}$ east of the northern end of the Antarctic Peninsula; not unexpectedly, the possibility that a sloth-indeed, that any xenarthranexisted during the Paleogene of what is now West Antarctica sparked much interest. First, at approximately $45 \mathrm{Ma}$, the Seymour specimen immediately became not just one of the earliest-known xenarthrans, but the oldest apparent sloth in the entire fossil record, exceeding the age of the next oldest contender by ca. $10 \mathrm{Ma}$ (MacPhee, 2005). Its identification as a xenarthran strengthened the argument that the Seymour fauna was closely related to Paleogene faunas distinctive of southern South America (cf. Case, 2006; Tejedor et al., 2009), adding additional weight to the notion that a terrestrial connection persisted between Patagonia and West Antarctica into the midPaleogene. Finally, the presence of a definite sloth in La Meseta sediments implied that, ca. $45 \mathrm{Ma}$, West Antarctica possessed an environment conducive to mammals preferring reasonably warm conditions (Carlini et al., 1990; but see Case, 2006).

MLP 94-III-15-14 is currently the only evidence of known whereabouts for the proposition that xenarthrans once lived in West Antarctica. (A second possible xenarthran from the La Meseta Fm of Seymour, a distal phalanx [MLP 88-I-1-95; DPV 6/84] possibly of vermilinguan or tardigradan affinity [Marenssi et al., 1994; Bargo and Reguero, 1998], cannot now be located in the MLP collections and therefore cannot be evaluated in this paper.) In one regard, failure to recover additional specimens is unremarkable, as mammal fossils are notably rare in $\mathrm{La}$ Meseta sediments and several nominal taxa are known only from one or two isolated teeth (Marenssi et al., 1994; MacPhee, 2008). Nonetheless, certain aspects of the original description, discussed in the following sections, put into question whether MLP 94-III15-14 can be securely referred to Tardigrada or even to Xenarthra. To investigate these doubts, the present authors conducted a new investigation, concentrating on histological aspects of the tooth as revealed by scanning electron microscopy (SEM). In addition to 

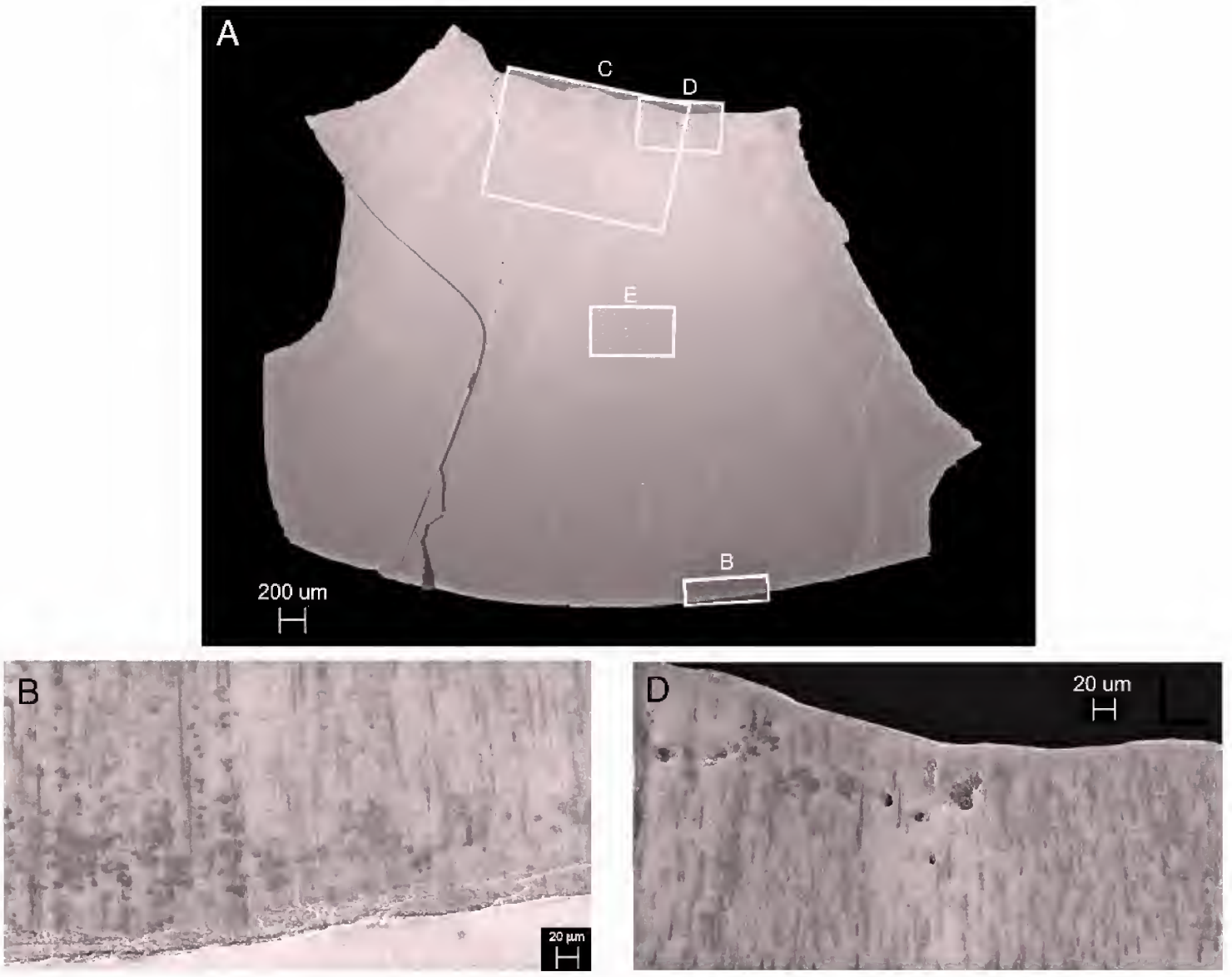

C

$\longmapsto 100 \mu \mathrm{m}$

\section{$\mathrm{E}$}

$\mapsto 20 \mu \mathrm{m}$
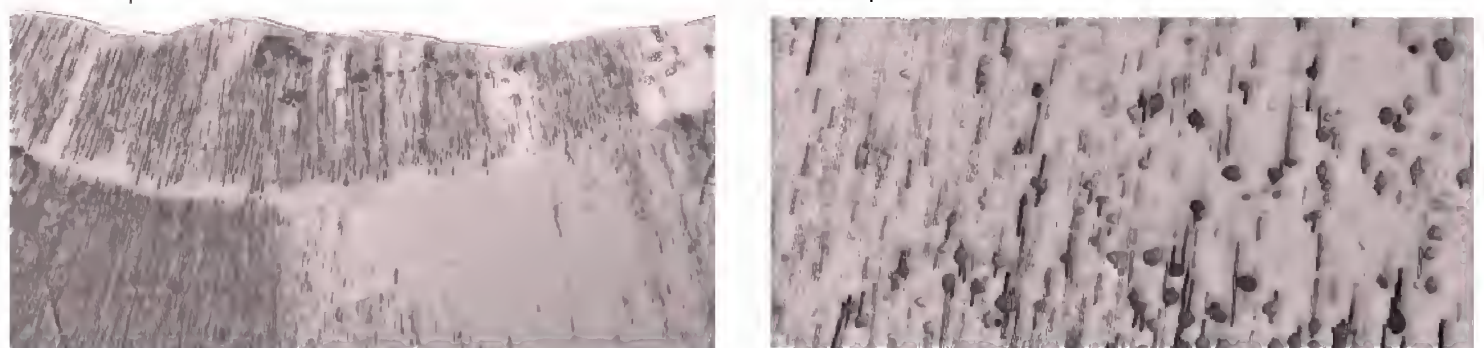

Fig. 2. MLP 94-III-15-14, incomplete tooth from La Meseta Fm, Seymour I., West Antarctica, sample cross section. A, entire section, with locations of areas illustrated in other views (B-E). Note indications of growth layers. B, external margin; despite some chipping which obscures visualization, tubules are in evidence throughout (i.e., zone of secondarily atubular orthodentine is lacking). C, pulp-cavity margin; plane of section is almost parallel to plane of tubules. The substance(s) producing the black pigmentation is unknown, but it was presumably derived from surrounding sediments during fossilization. D, pulp-cavity margin, close-up of apertures within dentine interpreted as channels for blood vessels; note that their distribution is very limited compared to the vascularized dentine of definite sloths. E, close-up of artifacts noted in C. Note that black areas are largely confined to the walls of tubules, and that individual dentinal tubules traced for a reasonable interval might be black-walled in one area but not in another. 
providing valuable data for assessing the status of the Seymour tooth, the SEM results were useful for re-evaluating previous interpretations of xenarthran dentinal histology based on light-optical methods.

\section{MATERIALS AND METHODS}

A small piece of the root end of MLP 94-III15-14 was detached and prepared for SEM (figs. 1, 2). The sample, a transverse slice running from pulp cavity to external surface, was embedded in epoxy resin and polished with increasingly finer grades of abrasives, ending with successive suspension slurries of 5.0 and $1.0 \mu \mathrm{m} \mathrm{Al}_{2} \mathrm{O}_{3}$. The preparation was examined without coating on a Zeiss EVO 60 EP-SEM ("environmental SEM") at $15 \mathrm{kV}$ and photographed at various magnifications. Specimens from a selected array of xenarthrans, living and extinct, were prepared in the same manner and compared to the Seymour tooth (figs. 4-10; appendix 1). Previous workers interested in sloth dental histology have tended to concentrate on mylodontans, megatheriid megatherians, and the extant genus Bradypus. Here we emphasize imaging of megalonychids (including extant Choloepus), partly because members of this family possess the most "caniniform" caniniforms among living xenarthrans (cf. Pujos et al., 2007). Cingulatans were not an original focus of this study but became increasingly relevant as work progressed. Published information on dental histology exists for a number of dasypodines and glyptodontids, but is sparse or nonexistent for the majority of other cingulatan taxa. We selected for study Euphractus and Chaetophratcus, two euphractines that appear to be particularly apt choices for comparison with the Seymour tooth because they similarly lack dentinal complexity.

Unfortunately, all the fossil specimens proved to be brittle during preparation, and most images are marred by hairline fractures. However, on the whole actual disruption was minimal and histological interpretation was not seriously affected.

\section{ABBREVIATIONS}

AMNHM American Museum of Natural History, Department of Mammalogy
AMNHVP American Museum of Natural History, Department of Vertebrate Paleontology

bv blood vessel

ce cementum

CU cuticle (dense connective tissue enwrapping tooth)

DPV Departamento Scientifico de Paleontología Vertebrados (used with locality identifier)

Fm formation

GL greatest length

MLP Museo de La Plata, Departamento Scientifico de Paleontología Vertebrados (used with specimen numbers)

OL outermost layer (of orthodentine)

SEM scanning electron microscopy

\section{REDESCRIPTION OF MLP 94-III-15-14}

Vizcaíno and Scillato-Yané (1995: 407) drew particular attention to four features of MLP 94-III-15-14 that, they argued, indicated in combination that the specimen could be attributed to a sloth: (1) tooth composed of dentine only, no enamel; (2) caniniform shape, with associated wear facet; (3) pulp cavity widely open, an indication of hypselodonty; and (4) three layers of dentine ("a hard external layer... separated from a softer central part by a thinner and clearer layer"). On the whole, they concluded that the strongest resemblances were to non-"orophodontid" tardigradans, "in which a wide core of soft dentine is surrounded by a thick layer of compact dentine."

Figures 1 and 2 illustrate the tooth in its present condition. The specimen appears uniformly black in ordinary light, but with SEM dark areas (i.e., areas that appear dark in electron-optical contrast) are unevenly distributed, especially internally (fig. 2B-E). Although the condition of the tooth is such that one cannot infer how much has been lost by abrasion, SEM inspection failed to reveal any kind of enamel, prismatic or nonprismatic, on the sectioned specimen. Absent also is any indication of cementum. By contrast, histological indications of dentine (tubules in amorphous ground substance) were conclusive for that tissue type. The external surface is lightly dimpled, smooth rather than rough, and without evidence of damage due to 
abrasion (as opposed to breakage). The specimen is gently rounded, with no crests apparent. As noted, the pulp cavity is apically widely open, which in adult mammals is strongly correlated with hypselodonty (MacPhee and Flemming, 2003).

While the specimen clearly tapered to a point when intact, half of the crown and probably much of the root is absent; thus, its precise conformation and original length are uncertain (fig. 1). Whether a major wear facet was ever present is impossible to say, because the tooth's apparent distal surface was already missing at the time of discovery. The few spall marks on the tip noted by Vizcaíno and Scillato-Yané (1995) are actually on the apparent mesial surface, and could be entirely the result of damage rather than wear. Its resemblance to caniniforms of any known sloth (including those with non-oblique wear facets, such as certain mylodontids) is thus rather vague. Certainly, there is no evidence that the specimen would have exhibited the broad, vertically oriented chisel surfaces seen on caniniforms of late Cenozoic megalonychids, which are especially trenchant in this regard (Gaudin, 2004; fig. 3).

As stated in the original description of MLP 94-III-15-14, lamellations or growth-layer groups (cf. Hohn, 2009) bounded by depositional arrest lines can be identified in ordinary light. Arrest lines are not frequently encountered in sloths (but see fig. 10), most of whom lived in warm climates where seasonality does not leave a strong imprint on tooth ontogeny (Klevezal, 1996). As is evident in figure 1C-D, there are many more lamellations than the three identified by Vizcaíno and Scillato-Yané (1995). These continue as discrete layers to the root end as a series of stacked chevrons, although this is difficult to ascertain in the photograph because of the specimen's condition.

If it is assumed that the arrest lines (such as the very prominent "dark line between external thick layer and other layers," feature 5 in fig. 1D) on the tooth mark the position of the dentinopulpal junction at specific times during the Seymour animal's life, then early in the tooth's development the pulp cavity must have extended to the tip of the crown. This inference is corroborated by the position of

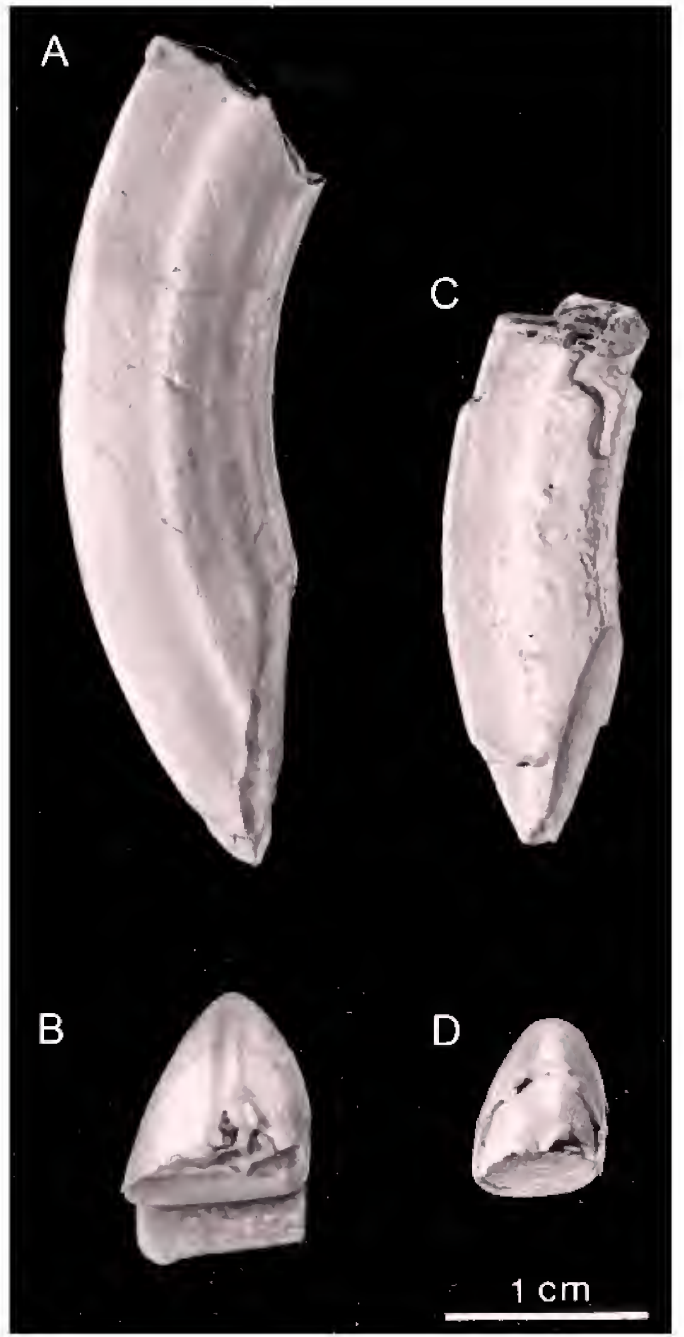

Fig. 3. Megalonychid maxillary caniniforms from a late Cenozoic locality in Grenada, West Indies. A, medial and B, adoral aspects (AMNHVP 132715); C, medial and D, adoral aspects (AMNHVP 132716). Note large chisellike wear facets. It is improbable that the Seymour specimen expressed a similar morphology. After MacPhee et al. (2000).

the central canal (feature 7 in fig. 1D), which marks the ontogenetically primary position of the pulp cavity. Such a canal can usually be detected in teeth of adult xenarthrans, but the feature also occurs in other mammals in which significant dentine deposition continues long into postnatal life (e.g., aardvarks, odontocete whales, dugongs; e.g., Owen, 1840-45). 


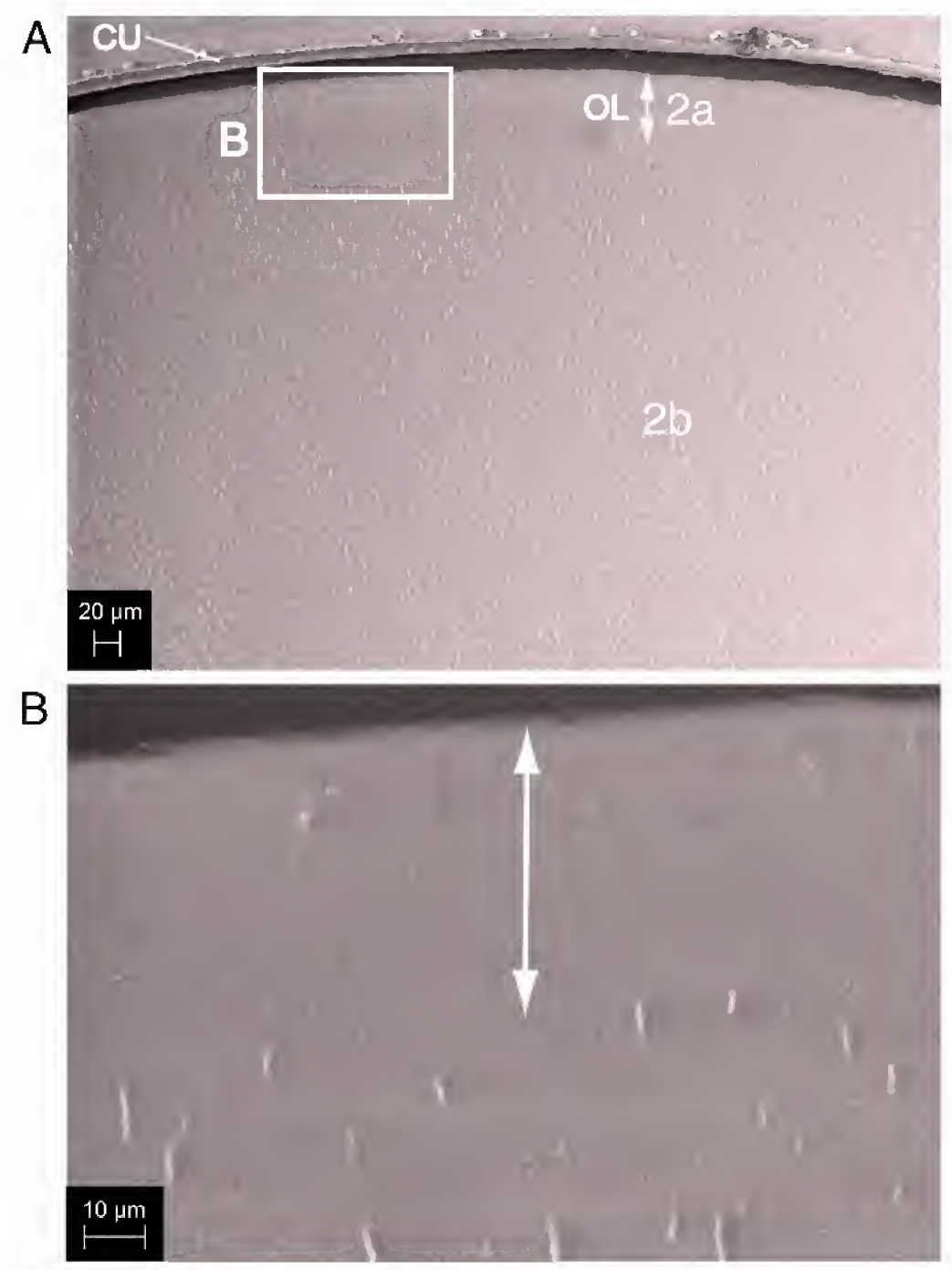

Fig. 4. Euphractus sexcinctus AMNHM 100075, upper molariform in cross section. A, tooth is formed completely from typical (avascular) orthodentine, including the central region where some evidence of blood vessels might be expected. Key to numbered, morphologically distinguishable tissues/areas: 2a, outermost orthodentine layer or OL (extent indicated by double-headed arrow) in which tubules absent or not readily apparent, no blood vessels; $2 \mathrm{~b}$, inner orthodentine with abundant, increasingly recumbent tubules, no blood vessels. The narrow strip of tissue (CU) separated from the rest of the tooth at the top of the photomicrograph is described as "cuticle" in Da Silva Sasso and Della Serra's (1965) histochemical study of Euphractus teeth; they stated that cementum as such is absent, although Ferigolo (1985: 72) claimed that a "thin and acellular" cementum was present on his specimens. Actually, the histochemical tests used by Da Silva Sasso and Della Serra to determine presence of glycoproteins and muccopolysaccharides are fairly nonspecific; they only establish that the cuticle is composed of some form of dense connective tissue which is not differentiated in the direction of bone, as would be expected if fully developed cementum were present. SEM observations are otherwise consistent with their interpretation. In this specimen the cuticle separated from the dentine during preparation, indicating it was only lightly attached. B, close-up of a small region along the tooth's periphery; recumbent tubules (bright features) decline sharply in abundance in the outermost layer of the orthodentine (double-headed arrow). On close inspection, ghostly outlines of filled-in tubules can be detected. 


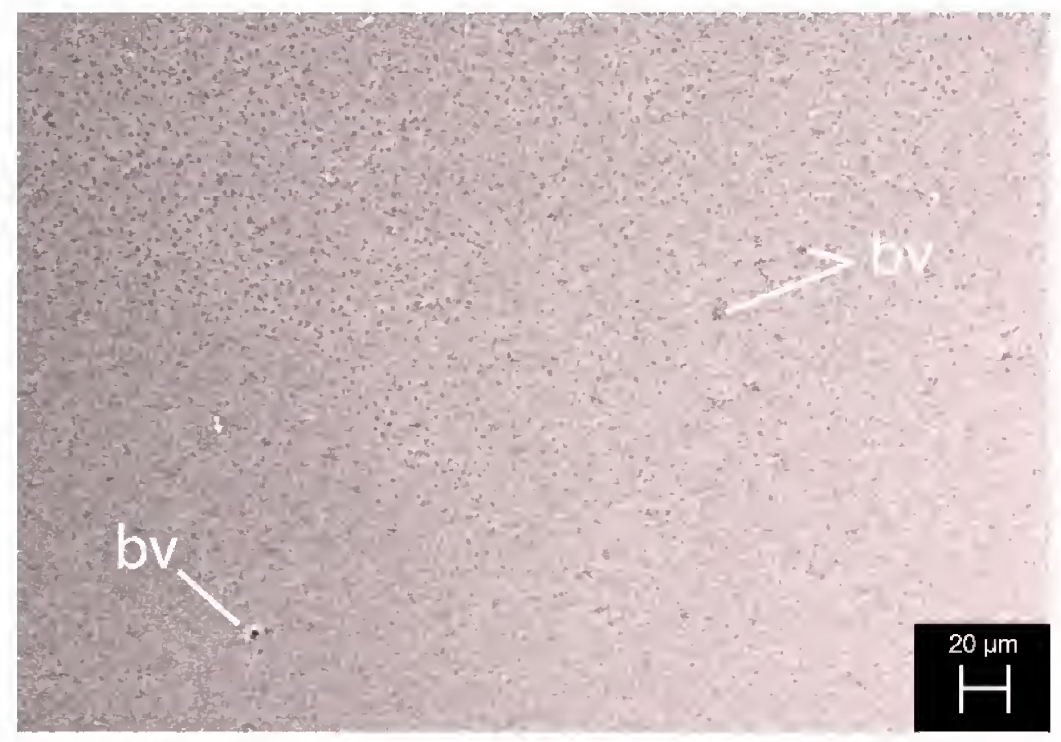

Fig. 5. Chaetophractus vellerosus AMNHM 246457, molariform in cross section. Within the dense array of tubules typical of orthodentine, there are occasional larger defects that appear to be for small blood vessels (bv). However, apertures are tiny and their frequency per unit area is much lower than in typical vasodentine (see fig. 6).

Using SEM, no gross difference could be detected between the dentines forming the exterior margin of the tooth, the dentine adjacent to the pulp cavity, and anything in between, unlike most of the taxa in the comparative set (figs. 4-10). Such uniformity implies that growth layers are compositionally extremely homogeneous. The only departure from gross structural uniformity in the available section of MLP 94-III-15-14 occurs in the zone adjacent to the pulp cavity, where a few tortuous holes indicate the probable presence of blood vessels in life (fig. 2D).

Other features seen in the cross section are best explained as artifactual. Under high magnification, "black" areas showing strong electron-optical contrast are almost entirely confined to the walls of the dentinal tubules (fig. 2E); intertubular areas are usually clear. Uptake, however, is highly variable, with some areas being completely bereft of dark matter. This suggests that the "thinner and clearer" areas may themselves be artifacts rather than a consequence of some sort of sclerotizing process during life (cf. Klevezal, 1996; cf. similar artifacts in a specimen of Acratocnus, fig. 9). It is also fairly apparent, at least on the basis of the one section available, that tubules do not undergo significant changes in size or direction. In mammals and perhaps many other vertebrates, dentinal tubules often curve and branch markedly; indeed, Boyde (1971: 87) thought that branching features were sufficiently diverse and possibly taxon-specific enough for them to be utilized in systematics (cf. Hildebolt et al., 1986). Unfortunately, this idea does not seem to have been followed up by subsequent researchers, at least for xenarthrans, but promising new techniques that will make investigation simpler are on the horizon (Kalthoff, 2008). In any case, with only a single preparation we cannot establish branching pattern or related variables for the Seymour tooth.

\section{COMPARISONS AND ANALYSES}

Our analysis in this section is based on comparisons of six features, treated in detail in following paragraphs, which we consider to be generally characteristic of xenarthran teeth. The first four have been examined sufficiently well in the literature for us to be reasonably 
certain that they are widespread within the group, if not precisely universal. The last two characters should be considered on test; at the histological level, tooth-bearing xenarthrans differ dentally much more than one might glean from available studies. Individuals, developmental stages, and even tooth loci in some species may differ in substantial ways that have rarely been taken into account.

To anticipate our chief conclusion, there are no features of the Seymour tooth that unambiguously tie it to known Xenarthra to the exclusion of other possibilities.

\section{Enamel normally absent}

It is of course parsimonious to assume that xenarthrans derive from eutherians in which enamel was present, as prismatic enamel occurs on tooth crowns of the early Paleogene dasypodoid Utaetus buccatus (Simpson, 1932), and enamel matrix has also been demonstrated conclusively in perinatal Dasypus novemcinctus (Martin, 1916). The relevant point is that in these cases the enamel layer amounts to no more than a thin scale, of little apparent significance for tooth function.

Wherever the correct affinities of the Seymour tooth may lie, there is no positive evidence for the presence of enamel in any form, while there is some negative evidence for its complete absence. For example, all external surfaces on the tooth are relatively smooth and shiny, which implies that no other hard tissues enwrapped it during life. If they had, then one would expect to see some histological evidence of a dentinoenamel or dentinocementum junction, as occurs in the teeth of typical mammals. Such junctions, when seen in section at high magnification (cf. Fawcett, 1986), are marked by tiny, irregular asperities, pits, and spindle-shaped processes of dentinal matrix (enamel spindles) that invade the enamel or cementum for a short distance. Functionally, these features presumably serve to limit the amount of torque developed along the junction interface during mastication, that, if left unconstrained, might cause the development of cracks between different tissue types. These microstructures are also responsible for the dull, rather rough appearance of dentinal surfaces exposed on fossil teeth with missing enamel or cementum-in marked contrast to the gently scalloped, reflective external surface of MLP 94-III-15-14. In sum, although not all relevant surfaces are preserved on the Seymour tooth, it is unlikely that an exterior coating of enamel could have been present at any stage.

\section{Cementum normally present}

An external wrapping of cementum, sometimes highly vascularized, has been counted as a universal feature of all adequately investigated xenarthrans (Gaudin, 2004), although its complete absence in some extant dasypodoids has also been claimed (see fig. 4). In any case, ample observational evidence reveals that cementum thickness varies in tooth-bearing xenarthrans from scarcely noticeable, as in some armadillos, to very significant, as in Megatherium (Ferigolo, 1985; Gaudin, 2004). In the latter taxon there is good evidence that a thick casing of cementum is mechanically significant in occlusal performance (Vizcaíno, 2009). Ferigolo (1985) noted a positive correlation in xenarthran taxa between the degree of vascularization and the amount of cementum present; those with the most vascularized teeth (such as Megalocnus and Neocnus in this study) also exhibited the greatest thickness of cementum. By contrast, in xenarthrans in which the functional role of cementum is more limited, this tissue tends to be thin and possibly only lightly anchored to the underlying dentine (cf. fig. 10). Thus, while we cannot absolutely discount the presence of cementum on MLP 94-III-14-15 during life, as in the case of enamel (see above) existing external surfaces provide no conclusive evidence for its presence.

\section{At least two kinds of structurally distinct dentine present (orthodentine and vasoden- tine)}

Since the time of Owen's investigations (1840-1845) it has been widely recognized that at least two kinds of descriptively different dentine comprise the teeth of almost all dentulous xenarthrans. However, this point requires some elaboration, as there are exceptions among armadillos (see below), and the nature of so-called "hard" vs. "soft" dentine has been inadequately explored.

To make headway here there is also a need to reduce the abundant-and notably redundant-nomenclatural terminology used to describe qualitatively different dentines found 


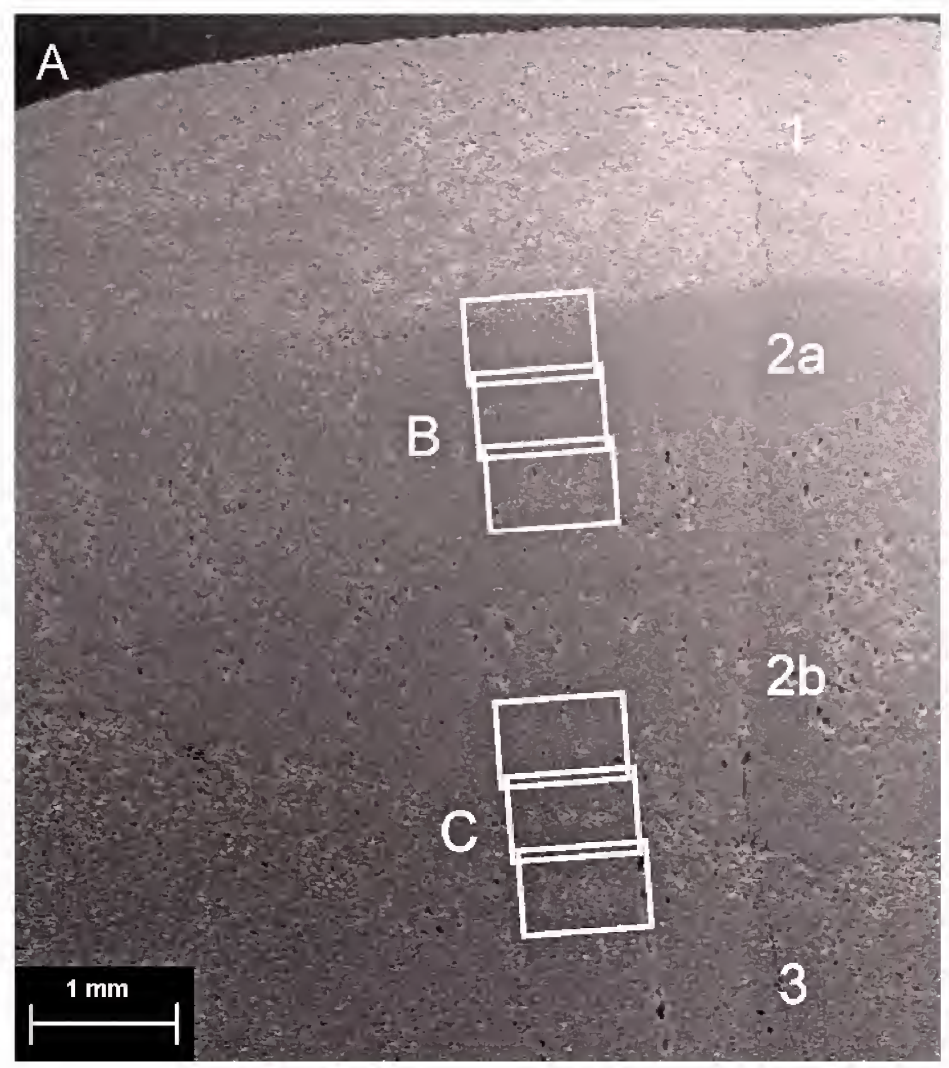

Fig. 6. Megalocnus rodens AMNHVP 143454, molariform in cross section. A, overview, with locations of image montages $\mathbf{B}$ and $\mathbf{C}$ indicated. Key to numbered, morphologically distinguishable tissues/areas: 1, cementum, with numerous blood vessels; at least some of the rounded apertures appear to be lacunae for cementocytes; 2a, outermost orthodentine layer (OL), tubules absent or not readily apparent, very few blood vessels; $2 \mathrm{~b}$, inner orthodentine with abundant, increasingly recumbent tubules and randomly distributed blood vessels; 3, vasodentine, with patterned distribution of many small blood vessels, some anastomosing with larger feeder vessels. $\mathbf{D}$ and $\mathbf{E}$, from another part of the tooth, are noncontiguous close-ups of the transitional zones between outermost orthodentine and cementum (D) and inner orthodentine (E), respectively. Note numerous recumbent, infilled tubules, much more evident at this magnification than in B.

in vertebrates (e.g., "orthodentine," "durodentine," "normodentine," "modified orthodentine," "orthovasodentine," "vasodentine," "secondary dentine," "intermediary tissue," "osteodentine"). For present purposes, we find the most useful contrast to be between the categories orthodentine and vasodentine. Avoiding unnecessary complication, vasodentine may be defined as "an incrementally deposited circumpulpar tissue permeated by passages for capillaries, but [generally] lacking tubules for extended odontoblastic processes" (Lund et al., 1992: 61), while orthodentine, which classically lacks blood vessels, is char- acterized by "numerous fine tubules from odontoblastic processes coursing parallel to each other" through the ground substance (Lund et al., 1992: 58).

As defined here, orthodentine occurs in almost every gnathostome class; vasodentine has a more restricted but still significant distribution (Arsuffi, 1938; Bradford, 1967). In xenarthrans the two types exhibit different mechanical properties (Keil and Venema, 1963; Vizcaíno, 2009; see below). Functional blood vessels incarcerated within dentinal tissues are rare in adult vertebrates generally, and decidedly so in mammals (for a list of taxa 

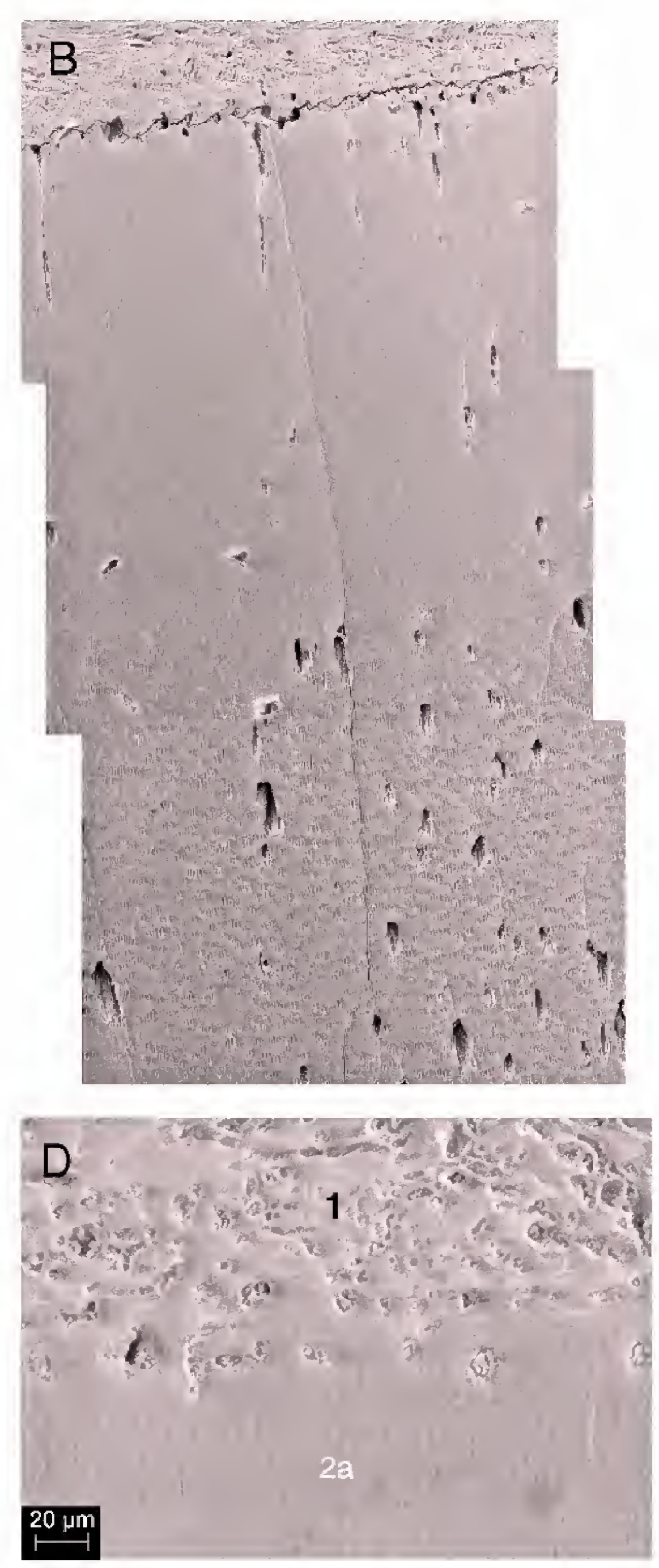

Fig. 6. Continued.

allegedly possessing this feature, see Arsuffi, 1938). Various kinds of intermediate states between typical orthodentine and vasodentine have been identified (e.g., Arsuffi, 1938; Ferigolo, 1985), but, as with all classifications of this type, it is vital to clearly separate end members, against which transitional variants
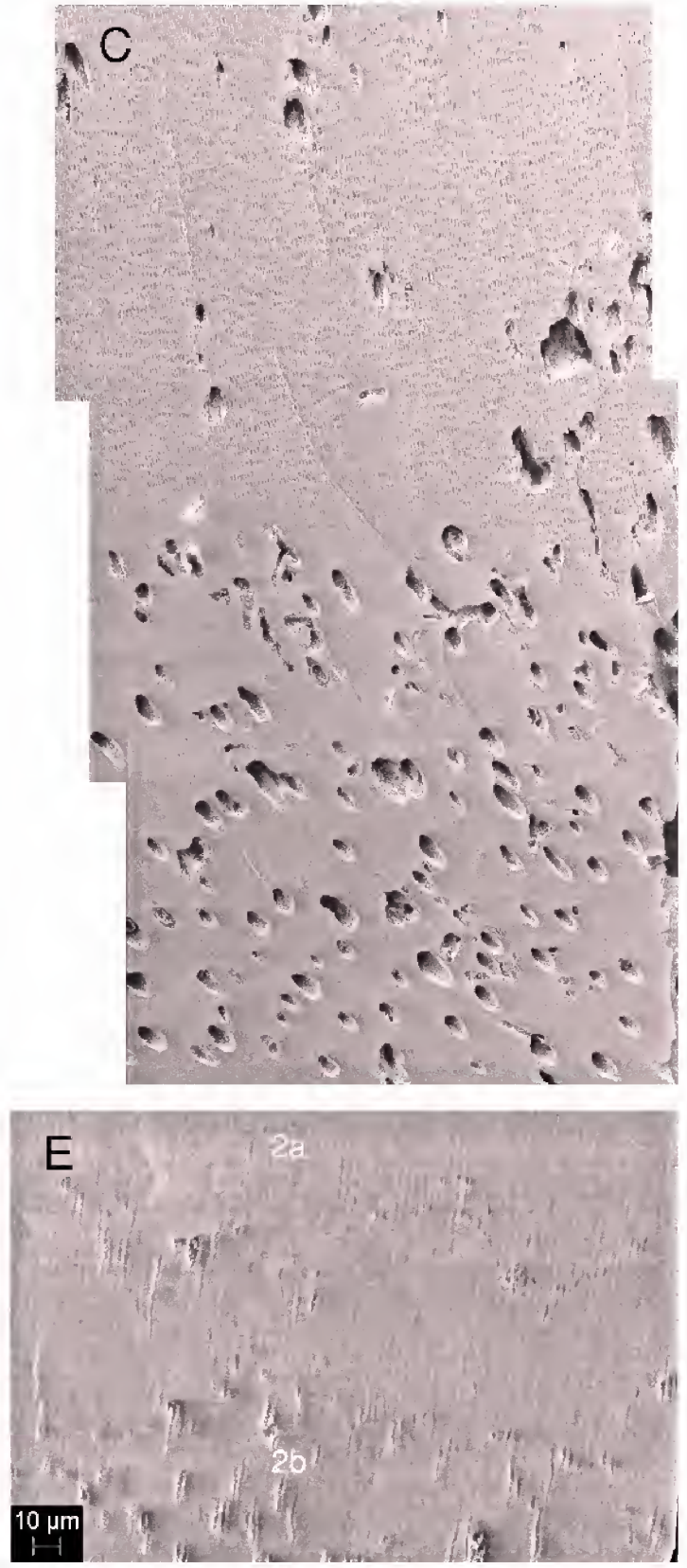

can be arrayed and compared. As in vertebrate dentines generally, in xenarthrans odontoblast cell bodies are absent within these tissues.

The outermost dentine of a tooth is always laid down in ontogeny as orthodentine, even if blood vessels also occur within it (cf. Neocnus; 

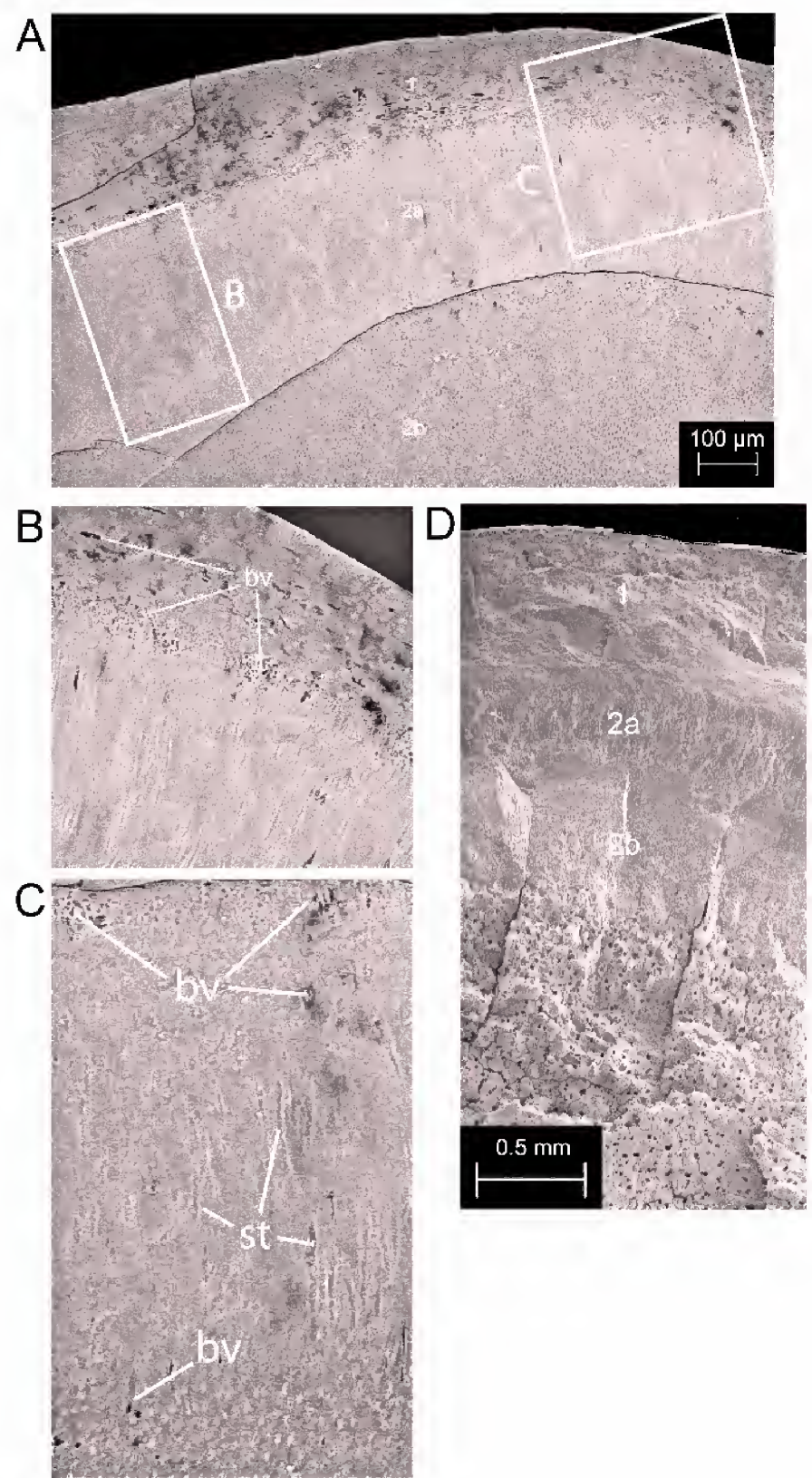

Fig. 7. Neocnus gliriformis AMNHVP 143453, molariform in cross section. Key to numbered, morphologically distinguishable tissues/areas: 1, cementum; 2a, outermost layer (OL) of orthodentine; $2 \mathrm{~b}$ inner orthodentine; 3 , vasodentine. Difference between $2 \mathrm{a}$ and $2 \mathrm{~b}$ is obvious in ordinary light as well, due to variable uptake of artifactual pigments in tubular vs. atubular orthodentine. A, overview of highly vascular cementum and orthodentine. B, close-up of cementum/orthodentine (OL) interface, marked by numerous blood vessels (bv) along borders of OL and within cementum. These appear to comport with similar concentrations of distinctively U-shaped blood vessels seen along this interface by Ferigolo (1985) in certain other sloths. C, close-up of entire section of orthodentine; long irregular features (st) appear to be the outlines of infilled vascular (bv) channels, although some may be infilled tubules. Because of uncertainty on this point they are simply identified as "striae." D, fresh fracture surface prior to grinding and polishing. 


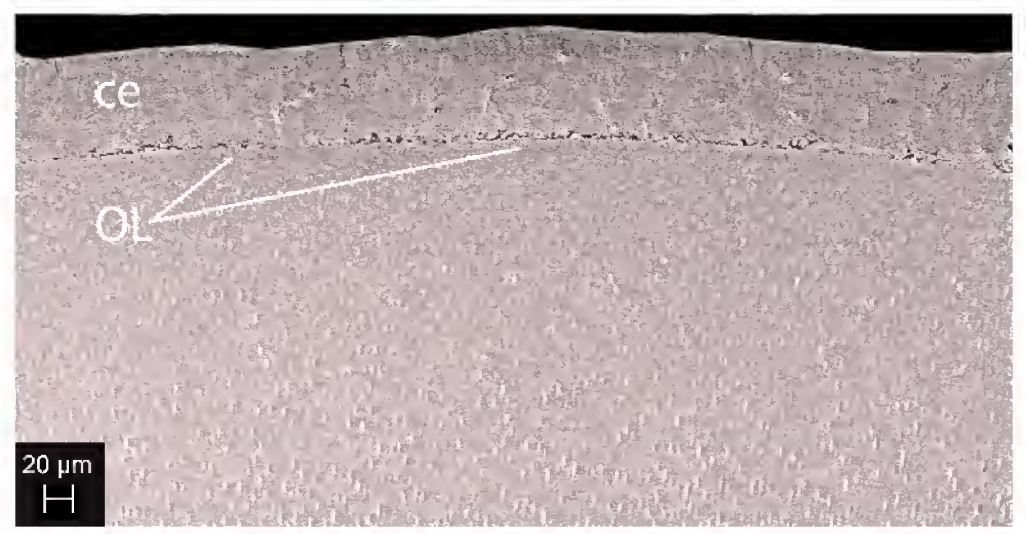

Fig. 8. Choloepus hoffmanni AMNHM 173551, caniniform in cross section. This tooth is composed of orthodentine (seen here) and a small core of vasodentine (not shown). The tubules immediately beneath the cementum (ce) become gradually more indistinct externally, but the true atubular outermost zone (OL) is very thin.

fig. 7A-C). This process continues as the dentinopulpal junction retreats rootward, as a consequence of later matrix being underplated onto pre-existing dentine. Zones of dentinal vascularization have been found in all sloths and most adult armadillos that have been properly investigated, which could be evidence that presence of vasodentine is primitive for these groups (cf. Gaudin, 2004; but see Ferigolo, 1985). There is, however, substantial variation in the size and number of blood vessels, as well as other features (figs. 410). For example, Ferigolo (1985) noted that some taxa display an "intermediary tissue," possessing both tubules and blood vessels (resembling Arsuffi's [1938] "orthovasodentine"), while in Bradypus tridactylus "in some cases the central dentine was almost amorphous [i.e., atubular] with only a few vascular canals or none" (Ferigolo, 1985: 72). The same author noted that, in Euphractus and Bradypus, vascularization is actually lost during the course of development (cf. figs. 4, 5). (Ontogenetic loss of vascularization also occurs in the dentine core of the incisors of some rodents according to Moss-Salentijn and Moss [1975] and is well attested in various fishes [Ørvig, 1951].)

In another deviation from the general xenarthran condition, the central figure in glyptodont teeth is comprised of a different structurally defined dentine (osteodentine) rather than typical vasodentine. However, large apertures occur within glyptodont osteodentine, which is presumably the reason that Owen (1840-1845: 325) referred to the "vascular osseous texture" of the latter (see also comments by Lund et al., 1992: 60). Ferigolo (1985) believed that osteodentine occurs more widely among xenarthrans, but did not illustrate any new examples. A tissue with some characteristics of bone (e.g., lacunae) lines the pulp cavity of the specimen of Glossotherium illustrated in fig. 10 , but its preservation is too poor for definitive identification. Microanatomical conditions in the teeth of Pseudoglyptodon, regarded by some authorities as a close relative of tardigradans (McKenna et al., 2006), are unknown; there are certainly no macroanatomical resemblances to the Seymour tooth.

Although the dentines of unquestionable xenarthrans do show some amount of morphological variation, the Seymour specimen still stands apart. As noted previously, only one type of dentine (with tubules, thus orthodentine by default) seems to compose the latter, with the dubious exception of a restricted vascularized zone near the pulp cavity. Nor do the numerous growth layer groups correlate in any obvious way with expected gross differences between "hard" and "soft" dentines as seen in definite sloths. These points bear on the evaluation of the next two characters as well. 

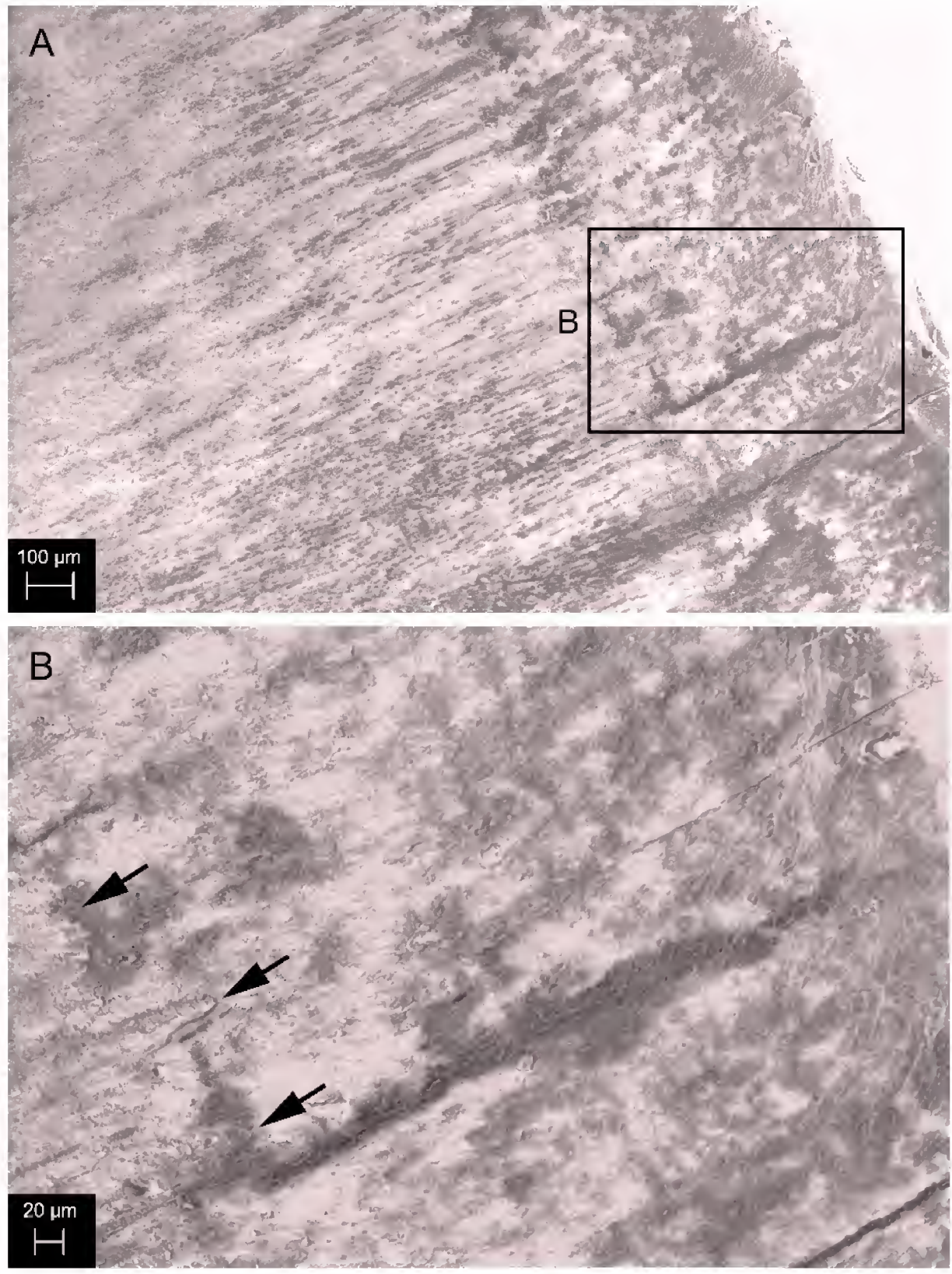

Fig. 9. Acratocnus antillensis AMNHVP 143452, caniniform in cross section. The tooth was broken at midshaft in order to undertake SEM; images are of the unpolished fracture surface (cf. fig. 7D). As is the case with other fossil sloth teeth depicted in this paper, image intelligibility is affected by noisy artifactual pigmentation. In $\mathbf{A}$ it can be seen that the tubules become more recumbent toward the exterior, but after a short transition cannot be traced further. In $\mathbf{B}$, a close-up of the transitional area, the line of tubule termination (black arrows) is very distinct. At least in this area, no tubules can be traced into the amorphous outermost layer to the left. Cementum may not have been present on this specimen; in any case, there is none now. 


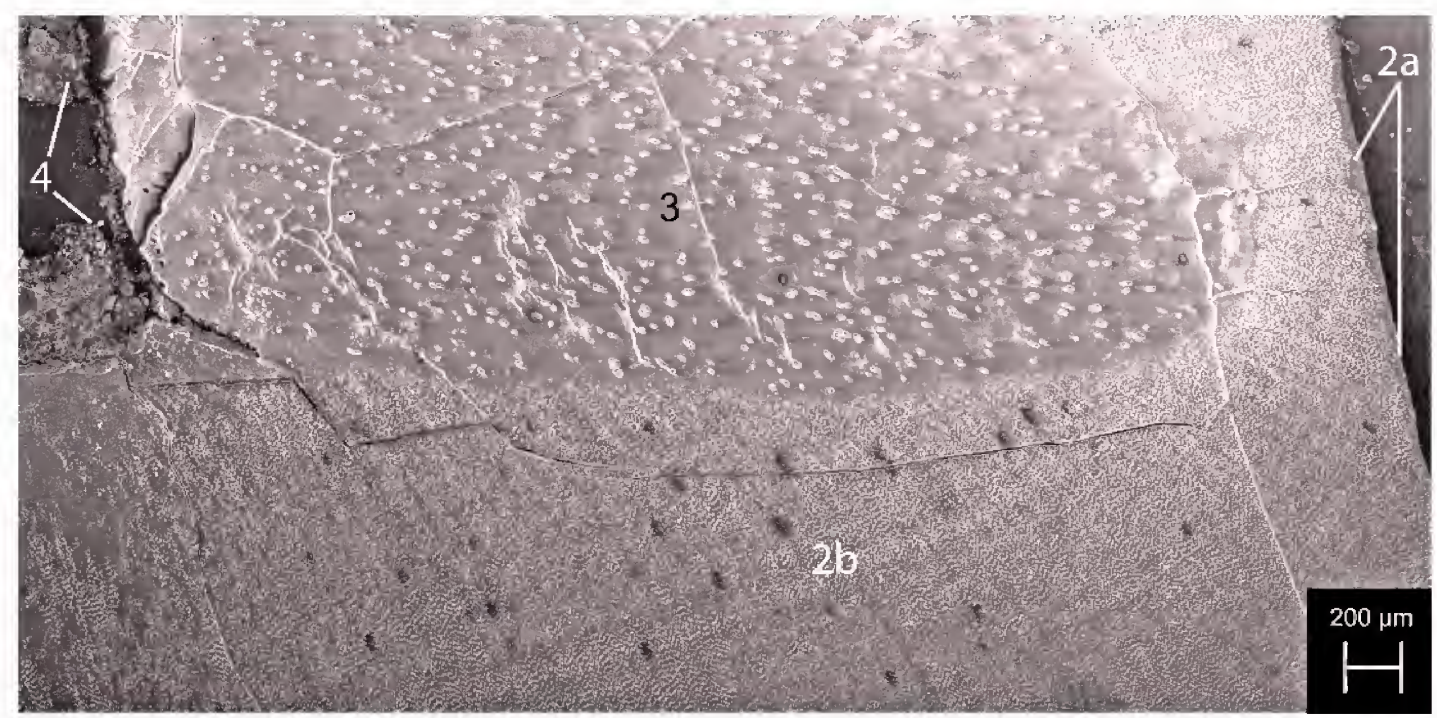

Fig. 10. Glossotherium sp. AMNHVP 143455, molariform (root end) in cross section. Unfortunately this specimen, from a tar seep in southwestern Trinidad, suffered substantial fracturing during preparation. However, tissue types are well differentiated. Key to numbered, morphologically distinguishable tissues/ areas: $2 \mathrm{a}$, outermost layer of orthodentine $(\mathrm{OL}) ; 2 \mathrm{~b}$, inner orthodentine; 3 , vasodentine; 4 , ?osteodentine. (Cementum is present as a thin layer on other parts of this tooth, but had spalled off on the root end and is thus not represented.) The outermost layer is very thin, as in the specimen of Choloepus (fig. 8), but as would be expected in light of conditions in other sloths examined here, the layer lacks patent tubules. Arrest lines, perhaps equivalent to growth layer groups, are moderately prominent in the lower part of the image within the inner orthodentine.

\section{Outermost orthodentine is moderately to completely atubular}

A little-noted peculiarity of many, if not all, xenarthrans is that the dentine formed first in ontogeny mostly lacks patent tubules in the adult. In the montages of SEM images of the Megalocnus rodens molariform in figure 6, it can be seen that tubules, very prominent in the orthodentine forming the middle portion of the tooth, become suddenly much sparser and tend to disappear altogether in the outermost layer (OL), except for occasional ghostly outlines. The effect is not necessarily constant all the way around the tooth; the degree of tubule obliteration may vary from area to area, but it is distinctly noticeable when deeper and more superficial layers are compared.

The fact that tubule remnants can be identified at all indicates that the OL is secondarily atubular. In $M$. rodens vascular channels also occur in the OL, but are infrequent. In the related taxon Neocnus gliriformis (fig. 7C) both structures occur in the OL, but outlines (striae) of infilled vascular channels seem to be particularly abundant.

Da Silva Saso and Della Serra (1965: 160, fig. 3) appear to have been the first to detect the existence of an external layer of relatively atubular dentine in the tooth of a xenarthran (Euphractus; see fig. 4). However, they interpreted the lack of tubules in a non-ontogenetic manner, suggesting that the majority of dentinal tubules simply terminated before reaching the outer margin of the tooth. This describes the adult condition, but does not account for its development. In all probability, the earliest deposition of dentinal matrix in Euphractus occurs around long cellular processes of active odontoblasts in the lining of the primordial pulp cavity, as in the standard vertebrate pattern. Later, however, most tubules (and vascular channels) traversing the OL become infilled, yielding the definitive condition of truncated tubules described here.

How this happens would have to be established experimentally and is therefore 
well beyond the scope of this study. However, it bears mentioning that, in the teeth of many nonmammals, orthodentine is covered by enameloid, a hypermineralized tissue. Thus, in the wrasse Labrus, tubules of orthodentine generally terminate at the enameloid border, but "some cross the boundary and run for some distance into the enameloid" (Bradford, 1967: 11), which is primary evidence that odontoblasts are involved in the formation of this tissue as well. Gillis and Donoghue (2007: 41), describing the histology and development of single-crystallite enameloid in various chondricthyans, noted that this tissue consists of "a monolayer of hypermineralized capping tissue... [that among other features] contains traces of odontoblast tubules... and lacking lines of incremental growth." In human dental anatomy, tubule obliteration is typically viewed as a pathological process, which weakens the dentine (e.g., production of "translucent" dentine by secondary hypermineralization, which alters the refractive index of the tubules in such a way that they become indistinguishable from ground substance; Warwick and Williams, 1973; Arnold et al., 2007).

True enameloid has not been recognized in any mammal, and it seems fairly clear that the xenarthran solution is different from that of fishes, in which a greater degree of tissue differentiation occurs. Nonetheless, the functional convergence is interesting, because in at least some xenarthrans the OL is actually the hardest part of the tooth, as Keil and Venema (1963: 181, fig. 8) demonstrated quantitatively in their study of microhardness (but without clarifying histological structure, which makes interpretation of their results somewhat difficult). In Euphractus, they showed that the exterior surface yielded the highest hardness measurement, but in this taxon cementum is either much reduced or replaced by a thin layer of cuticle only a few micra thick (see fig. 4), which implies that Keil and Venema (1963) had actually measured the outermost layer of orthodentine instead. The same interpretation applies to their results for Cabassous, which also exhibits a negligible amount of cementum (Ferigolo, 1985). The graph for the molariform of Dasypus indicates that its hardest part lies more internally. This, however, is still consistent with the observa- tion that the outer orthodentine is hardest, because in this taxon the teeth are externally wrapped in a thick layer of cementum (which is the tissue that they measured first). In any case, close inspection of molariforms of several different xenarthran taxa indicates that the true boundary between the "hard" and "soft" dentines of gross morphology most probably lies not between the orthodentine and vasodentine (or between cementum and dentine), as in most traditional descriptions, but within the orthodentine as we have defined it here.

In smaller xenarthrans (e.g., Euphractus, fig. 4) the absolute width of the OL is, of course, narrower than in a comparatively large taxon like Megalocnus (fig. 6). However, notice needs to be taken of variable conditions in megalonychids, in which the molariforms of some taxa (e.g., Neocnus; fig. 7A, D) possess a relatively well-developed OL, but the caniniforms of others (e.g., Choloepus; fig. 8) do not. The difference may underlie functional distinctions between the two tooth morphs: the caniniforms have a morphology consistent with their use for shearing, while the occlusal surfaces of molariforms function in crushing/ milling. Whether or not it is correct, this observation underlines our earlier point that significant morphological variation occurs among sloth tooth loci.

This observation is also pertinent for the evaluation of the Seymour specimen. Figure $2 \mathrm{~B}$ is a highly magnified view of the friable outer margin of the tooth; the edge was slightly chipped during preparation, but it is otherwise intact. Even though the quality of imagery is compromised by artifactual staining, no secondarily atubular zone is apparent with SEM, either here or elsewhere, and tubules continue to the margin of the tooth's external surface. In this regard the Seymour specimen differs from all examples utilized in this study, including Euphractus and Choloepus, both of which possess extremely narrow atubular zones in the outer orthodentine.

\section{Orthodentine restricted compared to vaso- dentine in molariforms}

Vizcaíno and Scillato-Yané (1995) assumed that the rather thick outer layer of dentine seen on the broken face of the Seymour tooth 
(fig. 1C) was equivalent to the "hard" dentine of xenarthrans, while the layers internal to it were compositionally "soft." This interpretation seemed to fit well with gross conditions seen in the majority of xenarthrans, in which orthodentine forms a comparatively narrow collar around a larger central core of vasodentine (cf. Gaudin, 2004). However, as noted above, SEM reveals that the Seymour tooth is histologically homogeneous except for a restricted zone next to the pulp cavity, in which a small number of vascular channels occur in addition to tubules. If, for the sake of argument, the latter is regarded as a form of vasodentine (or Ferigolo's [1985] 'intermediary tissue"), and the rest of the tooth as orthodentine, even though there is no perceptible structural difference between the two, then the resulting ratio of the two dentines (as measured from the pulp cavity to the external surface) is on the order of 1:9-essentially the reverse of the condition regarded as the dominant one in tardigradans, in which vasodentine forms the bulk of the tooth (e.g., fig. 6A).

However, once again conditions in definite xenarthrans display more complexity than tends to appear in systematic treatments. In at least some euphractine dasypodids, adult teeth lack vascularization completely, or almost so (figs. 5, 6). In Euphractus itself, vasculature is said to be present in young stages but later disappears (Ferigolo, 1985), although how channels are remodeled or infilled remains unexplored. In any case, although not all euphractine species have been studied, lack of dentinal vascularization may be a general feature of adult stages of this subfamily. Thus, in the central part of the tooth of the adult specimen of Chaetophractus vellerosus utilized in the present study (fig. 5), there are some holes, slightly larger than the apertures of the surrounding tubules, which very likely carried blood vessels. To this limited degree, the Seymour tooth may be said to resemble a morphological feature also encountered in a definite xenarthran.

\section{Flabellate arrangement of dentinal tubules}

A final interesting aspect of xenarthran dentinal histology that has not been widely commented upon by recent authors is a distinctive pattern of primary curvature in dentinal tubules. Tubules very rarely follow a straight course; in humans, in which tubule patterning has been most closely investigated, primary, secondary, and even tertiary curvatures have been described (Warwick and Williams, 1973). In dentulous xenarthrans, primary tubule orientation, viewed from central toward more peripheral regions in a given tooth, follows an arc that is initially semivertical but that becomes increasingly recumbent toward the tooth's external surface. This is best seen in longitudinal section in ordinary light, where tubule content and direction can be detected across the entire tooth. Cross sections are less reliable in this regard unless one has many sections in which tubule orientation can be evaluated.

This classic fan-shaped or "flabellate" arrangement of tubules was first described by Owen (1840-45: 324 and associated plates) in an armadillo: the "calcigerous tubes" (i.e., dentinal tubules), at first vertical, "rapidly diverge like the outer streams of a fountain"; they "bend outwards, and direct their course at right angles to the axis of the tooth, but with a slight convexity directed towards the grinding surface." In other cases the flabellate arrangement is more muted: Owen (1840-45: 336) noted for Mylodon that the "vascular dentine is permeated... by long, nearly straight and parallel vascular canals, proceeding, for the most part, outwards, and with a slight inclination to the grinding surface; this inclination is least at the base, and greatest at the summit of the tooth, where the vascular canals are parallel with the axis of the tooth." Similar conditions obtain in Bradypus and Dasypus (cf. Ferigolo, 1985, pls. 1-4). Using polarized light, Keil and Venema (1963) and Da Silva Sasso and Della Serra (1965) also documented associated transitions in collagen-fiber orientation in dentine ground substance.

Although variation certainly exists among extant xenarthrans for this character, and more comparative and quantitative data are needed to evaluate it properly, it seems reasonable to conclude that marked curvature is a dominant feature of dentinal organization in members of the superorder. All that can be said regarding the Seymour specimen is that evidence of similar curvature is lacking in the available section: tubules are essentially recti- 
linear, if somewhat undulating, and highly recumbent (trending horizontally with respect to the tooth's long axis) in all areas, including the areas closest as well as farthest from the pulp cavity. The broken distal surface gives no indication of tubule direction, but increasing verticality of tubules toward the mid-part of the crown seems inconsistent with the stackedchevron appearance of the different growth layers.

\section{CONCLUSIONS}

Microscopic study of MLP 94-III-15-14 reveals that this specimen-the sole specimen attributed to the "Seymour Island sloth"departs markedly from the morphology expected in definite tardigradans. The few microanatomical resemblances (mainly to armadillos) that can be cited are not compelling. Because of the incompleteness and poor condition of the specimen, it cannot be conclusively established that enamel and cementum were absent from the tooth during life, although it seems extremely unlikely that they were present. However, there are other informative features that can be assessed, and these provide a useful basis for making an informed decision about the specimen's taxonomic allocation:

1. Prior to damage, the Seymour tooth was probably conical, but there is no compelling morphological reason to identify it as a caniniform (as opposed to any other locus in a tooth row) in the absence of knowledge concerning the appearance of other teeth in the jaw from which it came.

2. The Seymour tooth appears to be composed entirely of one kind of dentineorthodentine, with the usual array of tightly packed tubules in an amorphous matrix. Laminations (growth-layer groups) can be identified under ordinary light, but with SEM they do not display histological or compositional differences that would provide a basis for identifying "hard" vs. "soft" dentine, contra Vizcaíno and Scillato-Yané (1995). Nevertheless, a few small channels, consistent with the presence of blood vessels, occur close to the pulp cavity. This observation might be grounds for recognizing a small zone of vasodentine; if so, as in other respects, the Seymour tooth stands at the far end of accepted xenarthran variation.

3. In the orthodentine of most of the definite xenarthrans examined here, a marked boundary exists between an inner zone in which tubules (and, in some taxa, vascular channels) are patent and an outermost zone (OL) in which tubules and/or vascular conduits are not evident. An identifiable OL is absent in the available section of the Seymour tooth.

4. At least in the available cross section, tubule orientation (curvature) does not appear to change in the Seymour tooth. Thus a flabellate arrangement of tubules is probably absent, although to demonstrate this conclusively a longitudinal profile would be required.

5. Considered together, these facts raise significant doubts concerning the previous systematic allocation of MLP 94-III-15-14. If the taxon it represents is to be retained within Xenarthra on the ground that no other allocation is likely, it cannot be placed with certainty in either of the major tooth-bearing groups within the superorder. To the limited extent that the Seymour specimen can be said to resemble teeth of any definite tardigradans or cingulatans, it is actually closer histologically to some armadillos than to any known sloths. Even then the resemblances are of a largely negative kind. A cogent example is the dentition of the adult euphractines investigated in this paper: the teeth are mere plugs, lacking cementum, vasodentine, and any sort of significant external layer of atubular orthodentine. The Seymour tooth displays a similar lack of complexity, but this would seem much more likely to be the result of convergence than common inheritance. In this connection it is relevant to note that scutes are almost always in high abundance whenever armadillos are present in a paleontological locality or stratigraphic section (Vizcaíno et al., 1998). After a quarter century of intense prospecting in La Meseta sediments by many different teams, it is surely meaningful that unambiguously cingulatan osteoderms have never shown up. 
6. Interestingly, the Seymour tooth could also be said to be morphologically as close to certain toothed cetaceans as to any xenarthran. Thus the first incremental line seen on the broken face of the tooth, bounding the layer that Vizcaíno and Scillato-Yané (1995) regarded as "hard" dentine, recalls the neonatal line that separates, in many extant odontocetes, prenatally deposited dentine from dentine deposited later (Hohn, 2009). Also, dentine tubules in modern toothed whales tend to be radially organized with a very slight primary curvature, and in young stages very little cement is present. Enamel occurs as a thin cap that may be worn away with use (Maas, 2009; R. MacPhee, personal obs.), although actual absence of enamel in unworn cetacean teeth seems never to have been noted in the neontological or paleontological literature (cf. O'Leary, 1998). Cetacean remains have been discovered in $\mathrm{La}$ Meseta deposits (e.g., Mitchell, 1989; Fordyce, 1989; Fostowicz-Frelik, 2003), although none so far described is an obvious source for the Seymour tooth. Nevertheless, Cetacea may be the logical place to look should more examples of this kind of tooth be found in future.

7. In light of the numerous qualifications that must now be applied to the acceptance of the xenarthran status of MLP 94III-15-14, we conclude that it is better relegated to Mammalia, incertae sedis, until its status can be more meaningfully resolved. (The more restricted allocation "Eutheria, incertae sedis" would also be appropriate, but as it offers no actual gain in understanding it is not adopted here.) Regrettably, this action removes the only available evidence for xenarthran presence in the Paleogene of Antarctica. Although there are some compelling compositional correlations between the Seymour mammal assemblage and various Patagonian faunas of Riochican and Vacan age (Reguero et al., 2002; Case, 2006; Tejedor et al., 2009), the precise fit of the former within the sequence of South American land mammal ages is not settled. Of great interest is the recent argument by Tejedor et al. (2009) that the La Meseta mammal assemblage correlates well with that of Paso del Sapo and coeval localities in western Patagonia, whose age may lie in the unconstrained "grey" area between Riochican and Vacan time (thus late Early Eocene). At these localities xenarthrans are represented in the form of several astegothere dasypodoids, including a new species of Riostegotherium, a genus otherwise known only from Itaboraí (long regarded as late Paleocene, but possibly considerably younger according to Gelfo et al. [2009]). However, the strength of the Paso del Sapo/La Meseta correlation will have to be tested with taxa other than xenarthrans: the Paso del Sapo fauna and its possible correlates lack recognizable sloths, while La Meseta Fm so far lacks any evidence of armadillos (and now, sloths as well).

\section{ACKNOWLEDGMENTS}

The senior author thanks his AMNH colleagues James Webster (facilities and materials for grinding and polishing sections), Becky Rudolph (SEM), and Lorraine Meeker (illustrations). We are grateful to Tim Gaudin (University of Tennessee, Chatanooga) and another reviewer for their helpful comments, Clare Flemming for editing the final manuscript, and Mary Knight for copyediting and overseeing the production of the published paper. Research related to this investigation was conducted under grant NSF OPP ANT 0636639 to the senior author.

\section{REFERENCES}

Arnold, W.H., V. Bietau, P.O. Renner, and P. Gaengler. 2007. Micromorphological and microanalytical characterization of stagnating and progressing root caries lesions. Archives of Oral Biology 52: 591-597.

Arsuffi, E. 1938. Beiträge zur Kenntnis des Vasodentins. Zeitschrift für Anatomie und Entwicklungsgeschichte 108: 749-760.

Bargo, M.S., and M.A. Reguero. 1998. Annotated catalog of the fossil vertebrates from Antarctica housed in the Museo de La Plata, Argentina. I. Birds and land mammals from La Meseta 
Formation (Eocene-?Early Oligocene). In S. Casadío (editor), Paleógeno de América del Sur y de la Peninsula Antártica, Asociación Paleontológica Argentina, Publicación Especial 5. Buenos Aires, 211-221.

Bradford, E.W. 1967. Microanatomy and histochemistry of dentine. In A.E.W. Miles (editor), Structural and chemical organization of teeth, vol. 2. New York: Academic Press, 3-34.

Boyde, A. 1971. Comparative histology of mammalian teeth. In A.A. Dahlberg (editor), Dental morphology and evolution. Chicago: Chicago University Press, 81-94.

Carlini, F., et al. (1990). The first Palaeogene land placental mammal from Antarctica: its paleoclimatic and paleobiogeographical bearings. Abstracts, Fourth International Congress of Systematic and Evolutionary Biology, University of Maryland, College Park, 1-7 July, 1990: 325.

Case, J.A. 2006. The late Middle Eocene terrestrial vertebrate fauna from Seymour Island: the tails of the Eocene Patagonian size distribution. Special Publication of the Geological Society of London 258: 177-186.

Da Silva Sasso, W., and O. Della Serra. 1965. Observações sôbre as estruturas de dentes de xenartros pertencentes aos gêneros "Dasypus", "Euphractus" e "Bradypus" (Edentata, Mammalia). Revista Brasileira de Biologia 25: 157-164.

Fawcett, D. 1986. A textbook of histology. 11th ed. Philadelphia: Saunders.

Ferigolo, J. 1985. Evolutionary trends of the histological pattern in the teeth of Edentata (Xenarthra). Archives of Oral Biology 30: $71-82$.

Fordyce, R.E. 1989. Origins and evolution of Antarctic marine mammals. In J.A. Crame (editor), Origins and evolution of the Antarctic biota. Special Publication of the Geological Society of London 47: 269-281.

Fostowicz-Frelik, L. 2003. An enigmatic whale tooth from the Upper Eocene of Seymour Island, Antarctica. Polish Polar Research 24: $13-28$.

Gaudin, T.J. 2004. Phylogenetic relationships among sloths (Mammalia, Xenarthra, Tardigrada): the craniodental evidence. Zoological Journal of the Linnaean Society 140: 255-305.

Gelfo, J.N., Goin, F.J., M.O. Woodburne, and C. de Muizon. 2009. Biochronological relationships of the earliest South American Paleogene mammalian faunas. Palaeontology 52: 251-269.

Gillis, J.A., and P.C.J. Donoghue. 2007. The homology and phylogeny of chondrichthyan tooth enameloid. Journal of Morphology 268: $33-49$.

Hildebolt, C.F., G. Bate, J.K. McKee, and G.C. Conroy. 1986. The microstructure of dentine in taxonomic and phylogenetic studies. American Journal of Physical Anthropology 70: 39-46.

Hohn, A.A. 2009. Age estimation. In W.F. Perrin, B.G. Würsig and J.G.M. Thewissen (editors), Encyclopedia of marine mammals. Amsterdam: Elsevier/Academic Press, 6-13.

Kalthoff, D. 2008. Tooth microstructure in fossil and recent sloth (Mammalia, Folivora). Journal of Vertebrate Paleontology 28 (3, suppl.): 98A.

Keil, A., and B. Venema. 1963. Struktur- und Mikrohärteuntersuchungen an Zähnen von Gürteltieren (Xenarthra). Zoologische Beiträge 9: 173-195.

Klevezal, G.A. 1996. Recording structures of mammals: determination of age and reconstruction of life history. Rotterdam: Balkema.

Lund, R., P.R. Bartholomew, and A. Kemp. 1992. The composition of the dental hard tissues of fishes. In P. Smith (editor), Structure, function and evolution of teeth. Tel Aviv: Freund, 35-71.

Maas, M.C. 2009. Bones and teeth, histology of. In W.F. Perrin, B.G. Würsig and J.G.M. Thewissen (editors), Encyclopedia of marine mammals. Amsterdam: Elsevier/Academic Press, 116-122.

MacPhee, R.D.E. 2005. "First" appearances in the Cenozoic land-mammal record of the Greater Antilles: significance and comparison with South American and Antarctic records. Journal of Biogeography 32: 551-564.

MacPhee, R.D.E. 2008. Austral portals and the paleobiogeography of Antarctic land mammals. Abstracts of Papers, Annual Meeting of the Geological Society of America 40 (6): 333.

MacPhee, R.D.E., and C. Flemming. 2003. A possible heptaxodontine and other caviidan rodents from the Late Quaternary of Jamaica. American Museum Novitates 3422: 1-42.

MacPhee, R.D.E., R. Singer, and M. Diamond. 2000. Late Cenozoic mammals from Grenada, Lesser Antilles Island-Arc. American Museum Novitates 3303: 1-20.

Marenssi, S.A. 2006. Eustatically controlled sedimentation recorded by Eocene strata of the James Ross Basin, Antarctica. Special Publication of the Geological Society of London 258: 125-133.

Marenssi, S.A., M.A. Reguero, S.N. Santillana, and S.F. Vizcaíno. 1994. Eocene land mammals from Seymour Island, Antarctica: paleobiogeographical implications. Antarctic Science 6: 3-15. 
Martin, B. 1916. Tooth development in Dasypus novemcinctus. Journal of Morphology 27: 647-691.

McKenna, M.C., and S.K. Bell. 1997. Classification of mammals above the species level. New York: Columbia University Press.

McKenna, M.C., A.R. Wyss, and J.J. Flynn. 2006. Paleogene pseudoglyptodont xenarthrans from central Chile and Argentine Patagonia. American Museum Novitates 3536: 1-18.

Mitchell, E.D. 1989. A new cetacean from the Late Eocene La Meseta Formation, Seymour Island, Antarctic Peninsula. Canadian Journal of Fisheries and Aquatic Sciences 46: 2219-2235.

Moss-Salentijn, L., and M.L. Moss. 1975. Studies on dentin. 2. Transient vasodentin in the incisor teeth of a rodent (Perognathus longimembris). Acta Anatomica 91: 386-404.

O'Leary, M.A. 1998. Phylogenetic and morphometric reassessment of the dental evidence for a mesonychian and cetacean clade. In J.G.M. Thewissen (editor), The emergence of whales, evolutionary patterns in the origin of Cetacea. New York: Plenum Press, 133-162.

Ørvig, T. 1951. Histologic studies of placoderms and fossil elasmobranches. 1: The endoskeleton with remarks on the hard tissues of lower vertebrates in general. Arkiv för Zoologi 2: 321-454.

Owen, R. 1840-1845. Odontography, or, a treatise on the comparative anatomy of the teeth; their physiological relations, mode of development, and microscopic structure, in the vertebrate animals. London: Ballière.

\section{APPENDIX 1 \\ COMPARATIVE SET}

\section{Cingulata, Dasypodidae, Euphractinae}

Chaetophractus vellerosus AMNHM 246457

(Holocene); Bolivia; lower molariform cross section

Euphractus sexcinctus AMNHM 100075 (Holocene), zoo specimen; upper molariform cross and longitudinal sections

Tardigrada, Megatheria, Megalonychidae

Choloepus hoffmanni AMNHM 173551 (Holocene); zoo specimen; upper caniniform cross section
Pujos, F., G. De Iuliis, C. Argot, and L. Werdelin. 2007. A peculiar climbing Megalonychidae from the Pleistocene of Peru and its implication for sloth history. Zoological Journal of the Linnean Society 149: 179-235.

Reguero, M.A., S.A. Marenssi, and S.N. Santillana. 2002. Antarctic Peninsula and South America (Patagonia) Paleogene terrestrial faunas and environments: biogeographic relationships. Palaeogeography, Palaeoclimatology, Palaeoecology 179: 189-210.

Simpson, G.G. 1932. Enamel on the teeth of an Eocene edentate. American Museum Novitates 567: $1-4$.

Tejedor, M.F., et al. (2009). New Early Eocene mammalian fauna from western Patagonia, Argentina. American Museum Novitates 3638: $1-43$.

Vizcaíno, S.F. 2009. The teeth of the "toothless": novelties and key innovations in the evolution of xenarthrans (Mammalia, Xenarthra). Paleobiology 35: 343-366.

Vizcaíno, S.F., and G.J. Scillato-Yané. 1995. An Eocene tardigrade (Mammalia, Xenarthra) from Seymour Island, West Antarctica. Antarctic Science 7: 407-408.

Vizcaíno, S.F., R. Pascual, M.A. Reguero, and F.J. Goin. 1998. Antarctica as a background for mammalian evolution. In $\mathrm{S}$. Casadío (editor), Paleógeno de América del Sur y de la Peninsula Antártica, Asociación Paleontológica Argentina, Publicación Especial 5. Buenos Aires, 199-209.

Warwick, R., and P.L. Williams. 1973. Gray's anatomy. 35th British ed. Philadelphia: Saunders.

Megalocnus rodens AMNHVP FM 143454 (L. Pleistocene/Holocene); Cuba; lower molariform cross section

Neocnus gliriformis AMNHVP 143453 (L. Pleistocene/ Holocene); Cuba; molariform cross section

Acratocnus antillensis AMNHVP 143452 (L. Pleistocene/Holocene); Cuba; upper caniniform cross section

Tardigrada, Mylodonta, Mylodontidae

Glossotherium sp. AMNHVP 143455 (L. Pleistocene); Trinidad; molariform (root end) cross section 


Complete lists of all issues of the Novitates and the Bulletin are available at World Wide Web site http://library.amnh.org/pubs. Inquire about ordering printed copies via e-mail from scipubs@amnh.org or via standard mail from: American Museum of Natural History, Library-Scientific Publications, Central Park West at 79th St., New York, NY 10024. TEL: (212) 769-5545. FAX: (212) 769-5009.

@ This paper meets the requirements of ANSI/NISO Z39.48-1992 (Permanence of Paper). 